\title{
Disclosure effectiveness in the financial planning industry
}

Authors: Dr. Daniel W. Richards ${ }^{1}$ and Dr. Maryam Safari ${ }^{2}$

\section{Purpose}

Scandals in the Australian financial services industry highlights the conflicts of interest between those who provide financial advice (financial planners) and their clients. Disclosure is a potential governance tool to manage these conflicts of interest by reducing asymmetries in information. Yet, the efficacy of disclosure is questionable as scandals persist, so we research the effectiveness of disclosure in financial planning.

\section{Design/methodology/approach}

This research used a qualitative approach involving the triangulation of data from parliamentary inquiries in financial services with data collected in semi-structured interviews with financial planning professionals.

\section{Findings}

The findings draw a clear portrayal of the disclosure requirements and illustrate how disclosure processes are onerous and complex. Starting with detangling the complex interactions between the beneficial role of disclosure in reducing information asymmetry and unethical behaviour and the detrimental effect of information overload, we then highlight effective disclosure techniques utilised by financial planners, including visualisation of material information. Our study reveals that financial planners perceive their role as filtering information for clients and ensuring clients' comprehension, due to the onerous disclosure requirements.

\section{Research limitations/implications}

The study is of interest to researchers, practitioners, policymakers, and society as it implies that how disclosure occurs is as important as what information is disclosed. Those who wish to foster effective disclosure in the financial services industry need to consider the quantity, quality, and process of disclosure. A limitation is our research focuses on financial planning practices and not client outcomes, which could be considered in future research.

\section{Originality/value}

The study adds to the understanding of how disclosure is utilised as a governance tool, and how the quantity of information may impede the effectiveness of disclosure in the financial planning industry. In addition, the study identifies and elaborates on the influential factors and best practices for enhancing the disclosure effectiveness by financial planners.

Keywords: Financial Planning, Financial Advice, Disclosure, Information Overload, Information Asymmetry

JEL codes: G50, D14, D82, G59

${ }^{1}$ School of Administrative Studies, York University, Ontario, Canada, danwrich@yorku.ca 
${ }^{2}$ School of Accounting, Information Systems \& Supply Chain, RMIT University, Melbourne Australia

Qualitative Research in Financial Markets has accepted this paper to publish with the doi https://doi.org/10.1108/QRFM-04-2020-0060 . The volume and issue numbers have not yet been assigned to the paper. The authors have signed copyright agreement with the Emerald and transferred the publishing rights to them. Emerald will publish the paper as soon as the journal requests them to do so. 


\section{Introduction}

Financial planning is an emerging profession that has evolved as a separate vocation from insurance broking, law, and accountancy (Cull, 2009; Murphy, 2018). Recently, financial planning has attracted great government and media attention worldwide (Chauhan and Dey, 2020). Some of the attention is due to a dual agency role of financial planners where they are agents for clients, but also agents for financial product providers, creating conflicts of interest (Chen and Richardson, 2018; Richards and Morton, 2020). These conflicts of interest are exemplified by the scandals which persist in this industry (Steen et al., 2016). One response to such controversy has been to increase the disclosure requirements of a financial planner when providing advice to clients (McInnes, 2020). The logic underlining this proposition is that disclosure will reduce information asymmetry and unethical behaviour (Luo et al., 2019; Nagar et al., 2019). However, it remains unknown how increased disclosure could serve as an effective governance mechanism for financial planning.

One school of thought suggests that unethical behaviour is eliminated by transparent disclosure. Enhancing transparency, through a good governance structure, enforces quality disclosure and assists informed decision making (Mallin et al., 2004). Some studies on corporate governance and environmental disclosure illustrate that a high level of disclosure is an effective corporate governance tool for alleviating principal-agent problems (Aksu and Kosedag, 2006; Patten and Trompeter, 2003; Francis, et al., 2008). However, an alternative perspective is expressed by the International Accounting Standards Board ([IASB] 2017) which identifies problems with excessive disclosure as being either irrelevant or ineffective communication of information. In addition, large disclosures of information may lead to information overload, reducing the effectiveness of disclosure (Saha et al., 2019). The dual agency role of financial planners, with the use of disclosure as a remedy, makes studies into disclosure in financial planning of the utmost importance.

Highlighting the importance of policy implications of disclosure studies, Kozup et al., (2012) assert that additional studies are required in many areas, particularly research on human factors, to help enable effective disclosure policies and practices. The financial planning industry has a significant societal impact with 2.3 million Australian people receiving financial advice in 2016 (Australian Securities and Investment Commission [ASIC], 2017a). Despite this, the literature on disclosure in financial planning is scarce (Steen et al., 2016) although, disclosure is frequently debated in the accounting literature (Saha et al., 2019). Our research addresses three key dimensions of disclosure in the financial planning industry. First, the study adds to the understanding of how disclosure is used as a governance tool to balance information asymmetries and to protect clients from potential conflicts of interest in the financial planning industry. Second, the study shows how the quantity of information may impede the effectiveness of disclosure in this industry; and finally, the study identifies and elaborates on the influential factors and best practices for enhancing the disclosure effectiveness by financial planners. A qualitative methodology, which involved content analysis of parliamentary inquiries and semi-structured interviews, was used to research these topics. 
Our findings first describe the process of disclosure in financial planning in Australia, outlining how it is onerous and complicated because multiple parties are involved with constructing disclosure documentation. The high volume of information disclosed causes information overload for clients and simultaneously becomes burdensome for financial planners. Next, we found that financial planners are of the opinion that most clients do not commonly read all the information disclosed. Thus, the role of the financial planner has become an information filterer who highlights important aspects to clients. This could provide an opportunity for financial planners to accentuate specific information favourable to their benefit. To provide solutions that enhance the quality of disclosure, results from this study suggest that regulating certain practices of disclosing information to clients would be beneficial. These include the importance of the initial meeting, face-to-face communication, clear and concise statements of advice, and visualisation of material information. The wide-ranging implications of the study for policy, practice, research, society, and educational purposes are elaborated later in the paper.

The remainder of the paper is structured as follows: Section 2 is a literature review in which financial planning is defined; the section also reviews the Australian financial planning industry, agency theory, and finally the benefits and detriments of disclosure. The methodology and data are discussed in section 3 and findings are presented in section 4 . A discussion of results is provided in section 5. Section 6 draws conclusions from the study.

\section{Literature review and conceptual framework}

\subsection{Defining financial planning}

Broadly defined, financial advice refers to information that is provided to influence a decision regarding a financial product (Richards and Morton, 2020). However, a distinction made by the ASIC is between personal and general advice. ASIC (2017b, pp. 10-11) defines personal financial advice as "circumstances where... the person giving or directing the advice has considered one or more of the client's objectives, financial situation, and needs ...or a reasonable person might expect the person giving or directing the advice to have considered one or more of these matters". ASIC (2017b) defines general advice as advice that is not personal. The personal advice definition reconciles with definitions of financial planning. Warschauer (2001 cited in Warschauer, 2002, p. 204) defines financial planning as "...the process that takes into account client's personality, financial status and the socio-economic and legal environments and leads to the adoption of strategies and use of tools that are expected to aid in achieving the clients' financial goals." In our research, we use the term financial planner as an advisor who provides personal financial advice. There are some industry professionals, such as financial advisors and accountants, who are not financial planners but do provide personal financial advice. Our research is also applicable to these professionals.

\subsection{Financial planning in Australia}

Financial planners in Australia historically came from a sales background (Cull, 2009) and this legacy remains. Reforming the financial services industry to counter this sales orientation has been an ongoing activity in Australia since 1997, when a parliamentary inquiry, known 
colloquially as the Wallis Report, recommended many changes to Australia's regulatory system and financial services (Hogan, 1997; McKeown, 2017). The Wallis Report noted a strong need to improve consumer protection in financial services. Thus, acts such as the Financial Services Reform Act (FSRA) 2001 and Chapter 7 of the Corporations Act 2001, have aimed to professionalise financial advice through the creation of a regulatory body (ASIC), instalment of a licencing regime, and uniforming disclosure in financial services. The disclosure requirements are product disclosure statements (PDS), financial service guides (FSG), and a statement of advice (SoA). These are outlined in more detail in section 4.1. Despite these initiatives, there have been persistent issues and scandals in financial advice, leading to more inquiries and reforms (McInnes, 2020).

More recently, the Australian government initiated two broad changes to financial advice; an increase in fiduciary duty (Batten and Pearson, 2013) and an increase in financial planners' educational, ethical and professional requirements (Financial Adviser Standards and Ethics Authority [FASEA], 2019). An increased fiduciary duty was incorporated through the Future of Financial Advice (FoFA) reforms from $1^{\text {st }}$ July 2013 which mandated that financial planners must base advice on what is in their client's best interest. FoFA also banned conflicted remuneration structures where financial planners receive remuneration from financial product providers that instil a conflict with fiduciary duty. In addition, FoFA mandated two additional disclosures which are an annual fee disclosure statement and an opt-in obligation (where clients must renew agreements to be charged on-going fees; see (Kingston and Weng, 2014; North, 2015)). There have also been calls to increase the educational standards, professional standards, and ethical values of financial planners (Steen, et al., 2016). Some of the initiatives implemented include a degree or equivalent level requirement for financial planners, a national examination undertaken by financial planners, and financial planners must adhere to a professional code of ethics (FASEA, 2019). The thrust of these reforms has been to strengthen the professionalism of financial planning by increasing education and ethical levels.

The governance mechanism used in financial advice is a licensing regime (McInnes, 2020). Under this regime, a financial services organisation obtains an Australian Financial Service (AFS) licence from ASIC and then authorises financial planners to practice as authorised representatives (financial planners can individually obtain their AFS licence but rarely do). In addition, financial product providers, who create the financial products that financial planners recommend to their clients need to obtain an AFS licence. The licencing regime awards significant power to the AFS licensee over financial planners (Richards and Morton, 2020). In addition, vertical integration has occurred where AFS licensee providing financial planning services are amalgamated or connected with financial product providers (Chen and Richardson, 2019). This creates conflicts of interest as a financial planner must weigh the interests of their AFS licensee against the interests of their client (Chen and Richardson, 2018; Richards and Morton, 2020).

In summary, a key driver within Australian financial planning is a move towards a 'client's best interest' model and away from a 'product provider interest's' model. However, the licencing regime does not structure a strict separation between those making financial products and those authorising financial planners to give advice. This occurs in large financial 
institutions but is less obvious for those financial planners who appear independent but are authorised by AFS licensees who create financial products. A means of managing these conflicts of interest is for a financial planner to disclose this information to the client. Next, this paper reviews disclosure as a method of managing conflicts of interest.

\subsection{Agency theory, conflicts of interests and financial planning}

Financial planners in Australia exist in an environment with agent-principal issues due to conflicts of interest (Chen and Richardson 2019; Richards and Morton, 2020). Acting as both a client's and financial product provider's agent sets financial planners in dual agency roles, which could trigger agency problems (Jensen and Meckling, 1976). Agency theory is normally used to describe a principal and agent relationship, where the agents (managers) may have different interests than the principals (shareholders) (Latimer and Maume, 2015). Here we use it to explain how financial planners (agents) have contrasting interests than clients (principals) due to the demands and rewards placed on financial planners by financial institutions. Latimer and Maume (2015 pp. 38) theorise that "disclosure will allow the monitoring of what the agent is doing to ensure that the agent is acting in the interests of the principal". In particular, disclosure can reduce information asymmetry where clients are unaware of the other interests which financial planners may have. In such an environment, disclosure could be used as a governance tool to mitigate agency problems and information asymmetries between financial planners and their clients (Chen and Richardson, 2018; Cheung and $\mathrm{Hu}, 2019)$.

\subsection{Benefits of disclosure}

Some literature illustrates that disclosure is a useful tool for managing the agent-principal problem. The Organisation for Economic Co-operation and Development ([OECD] 2015) describes transparency as management providing a clear and current representation of company affairs through timely and adequate disclosure on important aspects of a company such as its financial performance (Aksu and Kosedag 2006; Sharar 2006). Hirst and Hopkins (1998) argue that the quality of financial reporting will be enhanced by providing more transparent disclosure and this, in turn, enhances financial analysts' judgments. Patten and Trompeter (2003), in a study of disclosure, focused on environmental disclosure, and defended the effectiveness of higher environmental disclosure as a corporate governance tool for lessening accruals manipulation. Francis et al., (2008) focus on the extent of voluntary disclosure and financial reporting quality and concluded that higher quality in reports is significantly related to a higher level of voluntary disclosure.

The main aspects of quality disclosure considered in the literature are its 'timeliness' and the 'nature' of disclosure, which should ideally be factual, objective and consist of all material information (Edmonds et al., 2017; Schmidt and Wilkins 2013). In addition, the type of information that should be disclosed, who is in charge of deciding which information must be disclosed, and the monitoring of compliance are some of the issues that must be considered in companies' continuous disclosure policies. Comprehensiveness and transparency are identified as other characteristics of high-quality disclosure (Han et al., 2012). It's commonly suggested that relevant information should be provided to users in order to eliminate the surprise factor and that providing information about senior executives' employment agreements and 
remuneration will alleviate any element of surprise. The OECD's (2015) disclosure and transparency principles deal with users' equal and easy access to information and the need for timely, accurate, objective, and material information. The scope of disclosed information covers a company's financial situation, performance, ownership, and governance (OECD 2015).

The relationship between financial misconduct and disclosure quality is generally approached by combining two prior research streams (Jo and Kim, 2007): (1) studies that test disclosure quality and information asymmetry and (2) studies that investigate the relationship between information asymmetry and unethical behaviour (Lobo and Zhou, 2001; Welker, 1995). Jo and Kim (2007) find that entities with extensive and frequent disclosure will reduce information asymmetry and enhance transparency. Correspondingly, Lobo and Zhou (2001) show a negative relationship between the extent, quality, and informativeness of disclosure with misconduct and unethical behaviour. Prior research suggests that reducing information asymmetry is one of the potential benefits of disclosure (Lang and Lundholm, 1996; Lobo and Zhou, 2001). Dye (1988) introduces information asymmetry between managers and shareholders and between investors and prospective investors as two factors that generate misconduct. Similarly, Richardson (2000) shows a significant positive association between information asymmetry levels and financial misconduct. Generally, the findings of prior literature suggest a negative relationship between disclosure quality and information asymmetry (Welker, 1995).

Research from the marketing field outlines that disclosure can offer benefits for consumers. Garrison et al., (2012) discuss disclosure as a key component of consumer production policy and an instrument that could potentially help consumers understand the product features. They suggest the identification of key pieces of information, the use of principles of information design, and the thoughtful layering of the information essential to consumer understandability and usability. Similarly, in the context of consumer affairs Kozup et al., (2012, p.314) define a sound disclosure as "the direct linkage of a policy standard to a dedicated, rigorous consumer testing methodology that measures explicitly stated communication objectives put forth in the policy".

Although there have been extensive studies in the area of financial misconduct and the quality of disclosure (such as by Dye, 1988; Richardson, 2000; Trueman and Titman, 1988), and consumer affairs (Garrison et al., 2012), there has been little research in disclosure quality in the realm of the financial planning, despite its unique settings and disclosure requirements. Inderst and Ottaviani (2012), in a study on investigation of the determinants of the compensation structure for brokers in the financial advice industry, recommend policy intervention that mandates disclosure of commissions to protect naive consumers and increase welfare. In Australia, the FoFA regulations went further than disclosure of commissions by banning conflicted remuneration from product providers to financial planners (Batten and Pearson, 2013). This legislation also reduced associated perks such as soft dollar benefits (such as tickets to sporting games) to \$300 AUD (Batten and Pearson, 2013).

\subsection{Detriments of disclosure}


Recent studies, however, reveal detrimental aspects of information disclosure. The IASB noted that disclosure can lack comprehensive information, contain irrelevant information, or ineffectively communicate information (IASB, 2017). Too much disclosure can become burdensome and lead to an information overload problem. Saha et al., (2019) note that professional accounting bodies from Scotland and New Zealand issued the Excess Baggage Report in 2011 to combat the issue of too much information being disclosed. In doing so, the Excess Baggage Report classifies current International Financial Reporting Standards disclosure requirement items into three categories of retain, delete, and disclose if material (Saha et al., 2019). They find that those delete items are the least frequently disclosed items by Australian companies.

Psychological research into advice has unveiled interesting findings on advisors' and advisees' behavioural biases (Cain et al., 2005; Cain et al., 2011; Sahi, and Arora, 2012). Some literature asserts that recipients of advice may fail to accurately discount bias in advice when conflicts of interest are disclosed to them, suggesting that disclosure may not fully mitigate conflicts of interest (Cain et al., 2005; Sah and Lowenstein, 2014). Cain et al., (2011) attribute strategic exaggeration and moral licencing as reasons why advisors give more biased advice. Due to strategic exaggeration, advisors could give more biased advice to allow for discounting by the advisee when they receive the disclosure. Moral licencing could increase advisor bias because the practice of disclosing conflicts of interest will remove the moral responsibility of the advisor because the advisee has been informed (Cain et al., 2011). However, a recent financial planning experiment with conflicts of interest did not find evidence of strategic exaggeration or moral licensing (Chen and Richardson, 2018).

Cull and Sloan, (2016) introduced seven affective characteristics of trust as an essential element in building the client-advisor relationship. These characteristics include vulnerability, feeling, honesty, faith, best interests, accountability, and competence. Out of these characteristics they found honesty, with fees and commission earned by the advisor through the declaration of their remuneration clearly and upfront, one of the most relevant trust characteristics to the disclosure practices. Sah (2012) found that disclosure can decrease trust by an advisee of their advisor but also increase an advisee's duty to comply. Conversely, when disclosure occurs online (in a blog) by an advisor, an advisee's trust towards an advisor increases because the disclosure acts as a heuristic cue of integrity (Sah et al., 2018). Sah et al., (2018, pp. 18) investigated the reason for the inconsistent results and found that disclosure increased trust when advisees do not deliberate on the disclosure. They suggest that when advisees are presented with a lot of information to process, disclosure of conflicts of interest acts as a heuristic cue to trust the advisor. This research suggests that disclosure in person (and not online) and limiting the amount of other information advisees receive, could increase disclosure effectiveness.

In the context of the social economy sector (SES), Ghoorah (2019) explains the necessity and importance of financial disclosures by SES organizations as part of their accountability obligations. Nonetheless, a high volume of disclosure is also widely perceived as a problem as it may cause confusion by overloading users (Edmunds and Morris, 2000; Naynar et al., 2018; Stolowy and Paugam, 2018). In addition, drawing from behavioural models of rational choice, Chapman et al., (2019) asserts that a combination of information overload and users' time 
constraints would make the users susceptible to biases that can undercut the effectiveness of disclosure. Edmunds and Morris (2000) suggest the utilization of technology such as software solutions or information specialists to filter value-added information, as a solution for the information overload problem.

In summary, research on disclosure illustrates the relevance of this in financial planning for addressing an agency principal problem. It suggests that asymmetric information can be reduced by disclosure, however, there are benefits and detriments of the disclosure. To make disclosure effective, the quality of disclosure must be high. Furthermore, excessive disclosure could potentially be maladaptive, and the method of disclosing information could be important in making it effective. Our study focuses on addressing the following three key questions:

1. How is disclosure used in the financial planning industry as a governance tool to balance information asymmetries and to protect clients from potential conflicts of interest?

2. How does the quantity of information impede the effectiveness of disclosure in the financial planning industry?

3. What are the influential factors and best practices for enhancing the disclosure effectiveness in the financial planning industry?

\section{Methodology}

We adopted a qualitative approach to address our research questions because this allowed new ideas and new information to emerge while the research was undertaken (Bryman and Bell, 2015). The qualitative approach comprised of two phases conducted iteratively. The first phase involved content analysis of government inquiries and the second phase included in-depth interviews with financial planning professionals.

The archival data analysed in the first phase of research were the inquiries held by Australia's Parliamentary Joint Committee on Corporations and Financial Services (PJCCFS) and the Royal Commission into Misconduct in the Banking, Superannuation and Financial Services Industry (hereafter called the Royal Commission). This PJCCFS reviews industry-wide issues in Australia's financial system and reports findings to the government for policy recommendations. The process begins with the PJCCFS announcing the terms of references for the inquiry. Then, public submissions are collected, a careful review of information is conducted and then the PJCCFS draft a report (Parliament of Australia, 2017). These PJCCFS reports offered data on the industry-wide issues in financial planning. The researchers reviewed 63 inquiries and selected 21 of these for a more in-depth analysis, finding that the 5 outlined in Table 1 were pertinent for our research. In addition to the PJCCFS reports, we analysed the Royal Commission as this was also a public inquiry into the financial services industry. The Royal Commission published an interim report in 2018 and a final report in 2019. We analysed the PJCCFS reports and the Royal Commission to generate theories regarding disclosure in financial planning.

[Insert Table 1 here] 
The second phase of the research was to test theories through in-depth and semistructured interviews on disclosure with 12 financial planning professionals. This methodology is similar to direct content analysis, where it aims to validate or extend prior theory generated (Hsieh and Shannon, 2005). Qu and Dumay (2011, pp. 255) state "The benefit of the research interview lies in its unique ability to uncover the private and sometimes incommunicable social world of the interviewee, to gain insight into alternative assumptions and ways of seeing". Thus, ten financial planners and two financial services managers were interviewed to ascertain insights into disclosure quality and quantity issues. It was important to understand the perspective of financial planners as this perspective was missing from prior research (Chen and Richardson, 2018; Inderst and Ottaviani, 2012). The unstructured parts of the interviews provided information about the potential for policy enhancements, especially where quality, quantity, or presentation of the information seemed to be problematic (Greenwood and Hinings, 1993). Ethics approval was obtained from the university ethics committee and informed consent was obtained from the participants before interviews were conducted. The interviews, summarised in Table 2, were recorded at the respondent's consent and transcribed to enable analysis.

\section{[Insert Table 2 here]}

This research involved the triangulation of the two types of data collected (Kaczynski et al., 2014). We reviewed the information from the archival data to ascertain background information and terminology prior to conducting interviews. Six interviews were then conducted broadly around the concept of governance and disclosure in financial planning. Analysis of the archival data was reconciled with interviews and provided preliminary results. The method used to analyse this data was thematic analysis (Braun and Clarke, 2006), and the analysis was conducted using Nvivo 12 software. In total, the researchers identified six themes that pertained to disclosure: 1) information transparency vs overload on clients, 2) quantity of information, 3) quality of information, 4) improvements to disclosure, 5) presentation of information, 6) general disclosure issues. Following this analysis, a further six semi-structured interviews were conducted and analysed to verify and clarify these findings.

\section{Findings}

\subsection{Description of disclosure in Australian financial planning}

The first finding of our research pertains to how disclosure is used as a governance tool to balance information asymmetries and to protect clients from potential conflicts of interest in the financial planning industry. To address this topic, an understanding of the disclosure process is required. This is illustrated in Figure 1 and here we briefly outline who creates the various documents and the purpose of the documents to illustrate the disclosure process in financial planning in Australia. Disclosure requirements centre around three documents, which are the PDS, FSG, and an SoA. Additionally, two more requirements are a fee disclosure statement (FDS) and an opt-in requirement.

[Insert Figure 1 here] 
The PDS is created by the financial product provider and it details important aspects of the product provided which retail clients need. For each product recommended, a financial planner must disclose its PDS. According to the regulator, ASIC (2011), a PDS should be timely, relevant and complete, promote product understanding, promote product comparison, highlight important information, and regard consumers' needs. The FSG is created by the AFS licensee but provided to the client by the financial planner. The FSG explains the type of financial services being offered and it must be provided at the earliest practical opportunity before a service is delivered. Report 1 (p. 172) states "The primary means by which a financial adviser's conflicts of interest are currently disclosed is through an FSG." It outlines the information about the licensee, the services the licensee provides, remuneration details, and complaint resolution methods. Finally, the SoA outlines the advice being given and is generally prepared by financial planners. The industry regulator requires that the SoA contains the advice and the reasoning that led to the advice, information about remuneration and benefits; all conflicts of interest that may affect the advice; and the costs, loss of benefits, and other significant consequences when recommending switching between financial products (ASIC, 2017b).

In situations where financial planners have an ongoing fee arrangement with their retail clients, they must provide an FDS on an annual basis (Report 5, p. 27). Finally, on a biennial basis, the licensee must write to clients and receive feedback from them that they choose to opt-in to the ongoing fee arrangement (Report 5, p. 27). Report 1 recommended an annual optin practice.

The review of the disclosure requirements as presented in Figure 1 shows a substantial number of documents that must be disclosed by a financial planner to a client. There was a view from both the government regulator and by financial planners that clients are faced with information overload. Consider this quote:

"I think they [clients] get too much. I think the regulation forces them to drink from a fire hose. There's a lot of times when I had to go through things with my clients and they were literally saying to me, "I don't want to read it, I believe you, but where do I sign?" And I've gone, "Yeah, but I've got to go through these things. " (Respondent F)

It is important to note that a financial planner does not create most of these documents that need to be disclosed, which makes the disclosure more onerous. The financial planning industry is very disclosure orientated; a finding confirmed from interviews which viewed disclosure as a major governance tool in financial planning. One respondent stated:

"I think most of the legislation is actually about disclosure, not process. It's all about disclose, disclose, disclose to a retail client" (Respondent D)

The findings revealed that a reason for disclosure requirements could be lessening information asymmetry and agency problems. The awareness of information asymmetry between a financial planner and some clients was raised in the interviews where it was apparent that clients know less than financial planners do. Consider this quote: 
"So, when you talk about information, yes, advisors would have more information, ... because most clients that come to us are experts in their own field, but they come to advise us because while they have some idea of investment they know there's a lot more out there they possibly could use and that's why they come looking for an advisor who will basically fit their philosophy." (Respondent I)

In the government reports it was noted that one purpose of disclosure is to break down this information asymmetry:

"Regulation to protect investors is limited to conduct and disclosure requirements imposed on Australian Financial Services Licence (AFSL) holders. The purpose of these is... [to] overcome the information asymmetry between industry participants and investors by requiring disclosure of information required to facilitate informed decisions by investors" (Report 6, p. 7)

On the whole, disclosure is used as a governance tool to balance information asymmetries and to protect clients by having a large volume of information disclosed by three parties; financial planners, AFS licensees, and product providers. However, the financial planner is responsible for ensuring all disclosure is given to clients.

\subsection{Disclosure quantity and effectiveness}

The quantity compared to the quality of information is of utmost importance in financial planning disclosure. A finding of this research is that government regulators and financial planners believe that clients get more information than they can process. The large quantity of information means that clients do not read the information they are given. Interestingly, respondents $\mathrm{E}$ and $\mathrm{L}$ both noted that they did not read the information when they sought out financial advice for themselves. These quotes explain this further:

"this fallacy that you're a retail client so you need a Product Disclosure Statement, that is going to protect a client from making a mistake, it doesn't work. (Interviewer: Why?) Because no one reads the product disclosure statement in the first place." (Respondent C)

"By itself, simple disclosure of conflicts of interest is insufficient as a means of managing them. The whole regime of disclosure presupposes that what is given to a consumer in writing will be read, and if read, will be understood. Often, that presupposition is wrong. And given the length and complexity of FSGs and PDSs that is unsurprising." (Report 1, pp. 174-5)

Some financial planners noted that the amount of information overwhelms clients and they cannot process the information, impeding understanding by clients. One respondent noted:

"..the amount of information and rubbish that you get as a retail client with the Financial Services Guide and prospectuses and fee disclosure statements and all these sorts of things, to be honest, if you've got a good, transparent advisor with a good relationship, all this is doing is just getting in the road of that good relationship." (Respondent D) 
The seemingly large amount of information that needs to be disclosed to clients can have maladaptive effects. Given the quantity of information disclosed, financial planners expressed that a part of their job was to filter information and present only that which a client needs to know. Consider these quotes:

“Anecdotal feedback from my clients was ... 'I don't want to know everything. Just tell me what I've got to do.' And my job is to filter out all that stuff. So they expected me to know more, they expected me to have more information, and to filter out what they wanted to know and what was the right strategy for them." (Respondent G)

"...some clients love the details and have the capacity to digest all the legal wordings etc whereas others they do not care so for them you need to take a different approach" (Respondent F).

This illustrates that financial planners believe they have a role in deciding what information is relevant for a client (or not) and highlighting or emphasizing the relevant and material information. Conversely, from a legislative viewpoint, financial planners must disclose all information. Opportunistic attitudes of agents are predicted in agency theory and can use this filtering role for their own purposes by presenting information but accentuating certain aspects of it. This was noted in government inquiries (Reports 2 and 6) and illustrated by this quote by a financial planner:

"...your remuneration and your conflicts of interest and all that. So rather than bury them in page 45 of your report, I think you should bring them more upfront and say, here it is." (Respondent $\mathrm{H})$

In addition, Respondent $\mathrm{J}$ noted that a financial planner could emphasise only the advantages of a strategy and their client wouldn't realise they have omitted disadvantages. Report 1 notes that disclosure cannot mitigate all conflicts of interest. Thus, the emphasis in Australia (noted in Report 3) has been to improve financial planning quality through lifting professional, ethical, and educational standards of financial planners rather than through better disclosure alone.

Another effect is that the legal requirement to disclose information can rid financial planners of the responsibility to ensure a client understands the information presented to them. This was raised by respondent $\mathrm{H}$ and $\mathrm{J}$ but summarised aptly in these quotes:

"the onus is on the advisor, cause the clients are going to sign it or they're not. The onus is on the advisor to make sure the clients are fully aware of that. I think that's where discretion comes in where some advisors ...think, '[if the] Client signs it... I've done my job. I've given them the information, they decided not to read it, it's up to them'..." (Respondent G)

"I think this idea of disclosure is sort of like only half the story. I think the more important part as well; the people are coming to you because they don't understand. So, I think you have to have an obligation to explain, to make sure they understand." (Respondent $\mathrm{H}$ ) 
One reason why there was so much information being presented to clients, was that financial planners do not create the information being disclosed. This is created by licensees or financial institutions that they work for. These institutions take a compliance orientated approach to creating information rather than a communication-based approach. Respondents B, D, E, F, and G referred to this as a tick box disclosure approach. Consider these quotes:

"One problem is that the present arrangements enable or encourage licensees to take a risk-averse approach to compliance, rather than providing disclosure material that is focussed on informing consumers. In their submission ASIC noted that disclosure documents are often lengthy and complex, reflecting the nature of the products and providers' all-encompassing approach to legislative compliance. Such material is unlikely to serve informed decision-making where consumers are disengaged or unable to comprehend it." (Report 6, p. 82)

"Product providers will often provide whatever materials are required to just, make compliance requirements. Most dealergroups [AFS licensees] ... will say can you provide me the appropriate information that I need to put in the statement of advice and they [product providers] will know what is required... so they will be able to address the appropriate points. " (Respondent B)

When financial planners were asked about why they use information from the AFS licensee rather than write their own information, they spoke of a necessity to trust the information of the licensee:

"because of the volume of data, you've really got to trust your licensee or your research house, that is usually employed by your licensee, to provide accurate data." (Respondent G)

In addition, financial planners and government inquiries added that the complexity of information, and its meaning, is hard to communicate via disclosure because disclosure is often not relevant to a client's personal circumstances. This financial planner noted the duality of informational purposes by stating this:

"because they say from one hand we want it to be easy to read, understandable language that the client can engage with, so the advisor writes it as storybook, or from the other hand we need to cover all the terms and conditions, you need to tick all of these and its very rigid". (Respondent $\mathrm{F}$ )

Overall, the disclosure of information by financial planners is required to address asymmetric knowledge between planners and clients. Yet the amount of information financial planners must disclose is high and impedes apt disclosure. Financial planners reported that clients do not read all of the information or that clients feel overwhelmed by the amount of information. With this volume of information, financial planners view a part of their job as focusing the attention of clients on information which is important. However, financial planners could use the volume of information to accentuate the beneficial aspects and hide the detrimental aspects. Disclosing vast quantities of information may reduce a financial planner's 
obligation to ensure a client understands this information, especially when the financial planners do not create the information themselves. This can make disclosure a tick box exercise, rather than creating client understanding.

\subsection{Methods for quality disclosure}

Financial planners were asked about how they ensured that high-quality information was presented when so much information was required to be disclosed. The findings reveal that financial planners paid attention to how the information has been presented and how it is articulated to their clients. These factors are not often considered but play a key role in the usefulness of the information disclosed in financial advice.

\subsubsection{Initial meeting}

Firstly, financial planners spoke of the importance of the initial meeting with clients.

"I think when you - whenever I have an introductory meeting, we talk about the processes of how we go through the financial planning process and fees. So that just direct contact with the client." (Respondent E)

"Yes, so that is really part of the on-boarding, kind of boarding process in the upfront you know when we kind of pitch to a new client that that's what we are doing and how we are doing it. That's our lead-in really, that we are independent, and we are incentivised by any product provider and that's the investment piece." (Respondent A)

The first initial meeting was essential to make it clear to the client how the financial advice was being provided. It is also the time when financial planners had to provide the FSG.

\subsubsection{Face-to-face communication}

Secondly, financial planners spoke about the importance of face-to-face meetings as a way to explain information because it offers the chance for financial planners to get verbal and nonverbal feedback from clients. Consider these quotes:

"I'd rather do the face-to-face. So we've noticed, we either go to them, or they come to us, sort of thing. Because you can't...it doesn't make sense unless you can eyeball them. I could explain something to someone ... and then say, do you understand? And they just nod their head, and you know they don't. So then you've got to make sure that... and you can only get that feeling from actually the face-to-face discussion." (Respondent $\mathrm{H})$

\subsubsection{Statement of advice: relevant and material}

Thirdly, the financial planners prioritised disclosure in certain documents, with the SoA being the most informative document. This document connects the client to the advice they are seeking. It outlines the client's objectives, risk profile, and circumstances, which makes it personally relevant for the client and gains their attention. Thus, the quality of the SoA is of 
utmost importance. For example, respondent E explains the importance of an SoA to explain the expected volatility in a portfolio of an investor with a growth risk profile:

"Statements of Advice, again, I think they are important. The initial statement of advice because this is talking about what are your objectives, this is your risk profile, this is the asset allocation we think is appropriate for you, here is the level of volatility that you can expect. And clients need to understand that and if they don't understand it, at some stage you are going to hit a pothole. So you have got to get back and make sure that bit is right. Lots of clients will tell you I am a growth investor. Well, you are a growth investor until the markets are actually tested and then you really get to see if you are a growth investor or not. If they ring you up every other day saying the markets continue to fall, then you are not a growth investor." (Respondent E)

Respondent $\mathrm{K}$ noted that the importance of the SoA was that the clients could take this away, read it at a later time and come back with questions. This financial planner allowed 2 weeks between presenting the SoA and initiating any financial strategy to allow time for a client to raise questions. Respondent $\mathrm{L}$ also explained that the SoA should include the basis on which the advice has been given, information on any payments the advisor will receive, and all conflicts of interest that may affect the advice. They suggest a quality SoA should include material information that is clear, understandable, concise, and effective.

\subsubsection{Visualisation}

Finally, how information is articulated was raised in the research too, yet this is rarely considered by legislation. In addition to face-to-face meetings, financial planners argued the need to visualise information for clients through pictures, graphs, or videos. This was raised by respondent $\mathrm{K}$ and $\mathrm{L}$ also. Consider these quotes:

"It's got to be easily digestible. I use a lot of pictures because $70 \%$ of people are visual learners, $20 \%$ they love to see an Excel spreadsheet, and then $10 \%$ like to be spoken to. So bearing that in mind my SoAs are very visual with the outcomes and then it's written and then I state it." (Respondent G)

"They say a picture is worth a thousand words, right? So, it's very important to have pictures in the statement of advice. So, you can have grafts, you can have tables, you can have flowcharts just to show them what goes where, rather than have paragraphs of information." (Respondent I)

\section{Discussion of results}

The financial planning industry in Australia has been hit with scandals followed by legislation that seeks to improve financial advice through stricter controls on practitioners (Steen et al., 2016). One of the major forms of governance in these controls is disclosure whereby asymmetric information between financial planners and clients is deemed to be reduced through disclosure. The literature on disclosure supports that information asymmetry reduction is one potential benefit of disclosure (Lang and Lundholm 1996; Lobo and Zhou 
2001). However, literature also suggests maladaptive traits to disclosure, such as information overload (Saha, et al., 2019), strategic exaggeration, and moral licencing (Cain et al., 2005; Sah et al., 2012). There is a lack of literature on effective disclosure in financial planning to assess how disclosure is used and coherence of disclosure for financial planning.

To address disclosure in financial planning our research addressed how disclosure is used as a governance tool to balance asymmetric information, how the quantity of information impedes disclosure effectiveness, and finally what techniques are used by financial planners to make disclosure effective. The first finding of this paper was to describe the disclosure process in financial planning in Australia. This was necessary as the process is not intuitive because it involves financial planners disclosing information created by multiple parties, including product providers and AFS licensees. The findings revealed the existence of information asymmetry between financial planners and advisees, and the key role of disclosure is to break down this information asymmetry. However, disclosure by financial planners is onerous with various documents being disclosed, many of which are not created by financial planners. There were two main findings relating to the volume and complexity of information.

Firstly, there was a view that clients were not reading and processing all the information that they were provided, showing that information overload was occurring in financial planning. It could be argued that the amount of disclosed information commonly overwhelms clients and they cannot process the information, impeding clients' understanding. Secondly, due to the first finding, financial planners viewed part of their work as filtering information for clients by highlighting which parts were relevant. This filtering role, together with conflicts of interests for financial planners, could provide an opportunity for agents with opportunistic attitudes to accentuate certain aspects of information. The financial planners, however, unanimously stated the importance of honesty and trust for building and maintaining long-term relationships with clients.

Overall, the study finds that in relation to quantity compared to the quality of disclosure, financial planning in Australia is tilted more towards quantity. Given this, we investigated best practices for enhancing the disclosure quality by financial planners, given the aforementioned context they find themselves in. There were four main factors that financial planners raised to improve disclosure quality. There were; (1) the importance of initial meetings, (2) using faceto-face communication, (3) the importance of certain documentation such as the SoA, and (4) visualisation of material information. The importance of the initial meeting was to set precise standards for giving financial advice and the need for face-to-face communication was to get feedback from clients on their level of understanding. This feedback helped in understanding clients' needs to determine what information they should highlight for clients. Financial planners viewed the SoA as the key document for clients because it connected their objectives, risk profile, and circumstances to the recommendations, established the basis for the advice, and outlined any conflicts of interest. An SoA should be clear, concise and include relevant and material information to make disclosure effective. It is possible that visualisation of information to clients is one way to improve the quality of information when the quantity provided is very high. Future research could investigate whether clients understand financial disclosure more comprehensively when presented in visual or written formats. 


\section{Conclusion}

This study examined the effectiveness of disclosure as a governance tool in the financial planning industry. We adopted a qualitative approach comprised of two phases. The first phase involved content analysis of publicly available data to ascertain disclosure requirements, apparent issues and critically evaluate disclosure processes, quantity, and quality in financial planning. In the second phase (semi-structured interviews), we analysed the state of disclosure from the financial planners' perspective and identified best practices for quality disclosure. The findings drew a clear portrait of disclosure as a governance tool within the Australian financial planning industry. The paper then critically analysed the principal-agent issues, and the interaction between information asymmetry, relevant information, and information overload.

Our findings outlined how constructing and providing disclosure could be onerous and complicated. This may lead to information overload for clients and simultaneously become burdensome for financial planners. The findings of this study suggested that clients do not commonly read all of the information disclosed and that the role of the financial planner is an information filterer who highlights important aspects to clients (as perceived by the financial planner). This could potentially provide an opportunity for financial planners to accentuate specific information favourable to their benefit. The study also provided evidence for the importance of the initial meeting, face-to-face communication, clear and concise statements of advice, and visualisation of material information.

Disclosure topic has received little attention in financial planning despite it being a common aspect of providing financial advice. This research is not only adding to the fundamental understanding of disclosure practiced in the financial planning industry, but also has implications for future research, financial planning practice, education, and society which we address in turn. First, our research illustrated that how disclosure is used to govern financial planning throughout the world and a comparison of different disclosure systems, and how the systems balance quantity and quality of information, could garner insights into the benefits and deficiencies of this form of governance. More specifically, drawing from the diverse practices in the financial planning industry, it is revealed that 'how' disclosure occurs is as important as 'what' is disclosed. Future research could ascertain the relationship between how information is presented, when information is presented, and what information is presented, to find optimal disclosure practices. Specifically, our research highlighted four best practices adopted by financial planners and are worth researching further. In future research, it is also important to consider how disclosure can lead to better outcomes for consumers of financial advice.

Second, this research has implications for AFS licensees and financial planners which aim for high-quality disclosure. The study suggested that information should be presented in a manner and via a medium, which allows clients to understand it. The quality of an SoA was considered to be of utmost importance because clients focus on these documents as it relates to their personal circumstances. A quality SoA should be clear, concise, and include relevant and material information. The use of visual graphs or flow charts on material information was suggested to make information clearer and more understandable. In addition, having a mechanism to check a client's understanding (via face-to-face meetings or giving a client time 
to process the information) is important. These implications are also relevant to the education of financial planners. Financial planning education teaches what information is disclosed. An implication of our research is that financial planners need to be educated on how to disclose information and also how to ensure that a client understands disclosed information, to enhance the efficacy of the disclosure.

Finally, a societal implication of the study is associated with emergent financial and nonfinancial (e.g. behavioural, and psychological) benefits of the strengthened financial planning industry to the vast number of users. Trust in financial institutions has been reduced by scandals and malpractice (Report 1). Yet, many people in society rely on financial planners to make critical decisions. Thus, apt disclosure should improve the transparency of financial institutions and help clients to improve their decision making. An implication of the study for policymakers is they need to focus on both the content and the process of disclosing, to improve consumer's understanding and financial decision making. 


\section{References}

Aksu, M. and Kosedag, A. (2006), Transparency and disclosure scores and their determinants in the Istanbul Stock Exchange. Corporate Governance: An International Review, Vol. 14, No. 4, pp. 277-296.

Australian Securities and Investment Commission. (ASIC) (2011), "RG 168 Disclosure: Product Disclosure Statements (and other disclosure obligations)" available at https://download.asic.gov.au/media/1240931/rg168-published-28-october-2011.pdf (accessed November 20 2018)

Australian Securities and Investment Commission. (ASIC) (2017a), “ASIC's Corporate Plan $2017-18$ to $2020-21 "$ available at http://download.asic.gov.au/media/4439405/corporate-plan-2017-published-31august-2017-1.pdf (accessed 23 March 2020)

Australian Securities and Investment Commission. (ASIC) (2017b), "RG 175 Licensing: Financial product advisers - Conduct and disclosure." available at https://download.asic.gov.au/media/4698465/rg175-published-10-april-2018.pdf (accessed November 20 2018)

Batten, R. and Pearson, G. (2013), Financial Advice in Australia: Principles to Proscription; Managing to Banning. St. John's Law Review, Vol. 87 No. 2/3, pp. 511-559.

Braun, V., and Clarke, V. (2006), Using thematic analysis in psychology. Qualitative Research in Psychology, Vol. 3 No. 2, pp 77-101.

Bryman, A. and Bell, E. (2015), Business research methods (Fourth ed.). Oxford University Press: Oxford

Cain, D. M. Loewenstein, G. and Moore, D. A. (2005), The dirt on coming clean: Perverse effects of disclosing conflicts of interest. The Journal of Legal Studies, Vol. 34 No. 1, pp. 1-25.

Cain, D. M. Loewenstein, G. and Moore, D. A. (2011), When sunlight fails to disinfect: Understanding the perverse effects of disclosing conflicts of interest. Journal of Consumer Research, Vol. 37 No. 5, pp. 836-857.

Chapman, K. L., Reiter, N., White, H. D., and Williams, C. D. (2019), Information overload and disclosure smoothing. Review of Accounting Studies, Vol. 24 No. 4, pp.14861522 .

Chauhan, Y. and Dey, D. K. (2020), Does financial literacy affect the value of financial advice? A contingent valuation approach. Journal of Behavioral and Experimental Finance, Vol. 25, pp. 1-10.

Chen, P. and Richardson, M. (2018), Conflicted financial advice: disclosure revisited. Applied Economics Letters, Vol. 25 No. 12, pp. 826-829.

Chen, P. and Richardson, M. (2019), Conflict of Interest, Disclosure and Vertical Relationships: An Experimental Analysis. Economic Papers: A journal of applied economics and policy Vol. 38, pp. 167-181. 
Cheung, A. and Hu, W. (2019), Information disclosure quality: correlation versus precision. Accounting \& Finance, Vol. 59 No. 2, pp. 1033-1053.

Cull, M. (2009), The Rise of the Financial Planning Industry. Australasian Accounting Business \& Finance Journal, Vol. 3. No. 1, pp. 26-37.

Cull, M., and Sloan, T. (2016), Characteristics of trust in personal financial planning. Financial Planning Research Journal, Vol. 2 No. 1, pp. 12-35.

Dye, R. (1988), Earnings management in an overlapping generations model. Journal of Accounting Research, Vol. 26, No. 2, pp. 195-235.

Edmonds, C. T. Edmonds, J. E. Vermeer, B. Y. and Vermeer, T. E. (2017), Does timeliness of financial information matter in the governmental sector? Journal of Accounting and Public Policy, Vol. 36 No. 2, pp.163-176.

Edmunds, A., and Morris, A. (2000), The problem of information overload in business organisations: a review of the literature. International Journal of Information Management, Vol. 20 No. 1, pp. 17-28.

Financial Adviser Standards and Ethics Authority. (FASEA) (2019), “About us" available at https://www.fasea.gov.au/about/ (accessed 10 February 2020)

Francis, J. Nanda, D., and Olsson, P. (2008), Voluntary disclosure, earnings quality, and cost of capital. Journal of Accounting Research, Vol. 46 No. 1, pp. 53-99.

Garrison, L., Hastak, M., Hogarth, J. M., Kleimann, S., and Levy, A. S. (2012), Designing Evidence-Based Disclosures: A Case Study of Financial Privacy Notices. Journal of Consumer Affairs, Vol. 46 No. 2, pp. 204-234.

Ghoorah, U. (2019), “Accountability via Financial Disclosures: An Exploration of the Public's Perceptions" in A. Ferreira, R. Marques, G. Azevedo, H. Inácio, C. Santos (Ed.) Modernization and Accountability in the Social Economy Sector IGI Global, pp. $21-42$.

Greenwood, R., and Hinings, C. R. (1993), Understanding strategic change: The contribution of archetypes. Academy of Management Journal. Vol. 36 No. 5, pp. 1052-1081.

Han, S., Kang, T., and Yoo, Y. K. (2012), Governance role of auditors and legal environment: Evidence from corporate disclosure transparency. European Accounting Review, Vol. 21 No. 1, pp. 29-50.

Hayne K. (2018), Interim Report Royal Commission into Misconduct in the Banking, Superannuation and Financial Services Industry. Commonwealth of Australia

Hayne K. (2019), Final Report Royal Commission into Misconduct in the Banking, Superannuation and Financial Services Industry Volume 1. Commonwealth of Australia

Hirst, D. and Hopkins, P. (1998), Comprehensive income reporting and analysts' valuation judgments. Journal of Accounting Research, Vol. 36, pp. 47-75.

Hogan, W. (1997), What Directions from Wallis? Australian Accounting Review, Vol. 7 No. 14 , pp. $40-44$. 
Hsieh, H.-F. and Shannon, S. E. (2005), Three approaches to qualitative content analysis. Qualitative Health Research, Vol. 15 No. 9, pp. 1277-1288.

International Accounting Standards Board (IASB) (2017), "Disclosure Initiative - Principles of Disclosure, Discussion Paper DP/2017/1" available from http://www.ifrs.org/projects/work-plan/principles-of-disclosure/ (accessed $20 \mathrm{March}$ 2020)

Inderst, R. and Ottaviani, M. (2012), How (not) to pay for advice: A framework for consumer financial protection. Journal of Financial Economics, Vol. 105 No. 2, pp. 393-411.

Jensen, M. C. and Meckling, W. H. (1976), Theory of the firm: Managerial behavior, agency costs, and ownership structure Economics social institutions Vol. 3 No. 4, pp. 305360 .

Jo, H. and Kim, Y. (2007), Disclosure frequency and earnings management. Journal of Financial Economics, Vol. 84 No. 2, pp. 561-590.

Kaczynski, D., Salmona, M., and Smith, T. (2014), Qualitative research in finance. Australian Journal of Management, Vol 39. No. 1, pp. 127-135

Kingston, G., and Weng, H. (2014), Agency theory and financial planning practice. Australian Economic Review, Vol 47. No. 3, pp. 290-303.

Kozup, J., Taylor, C. R., Capella, M. L., and Kees, J. (2012), Sound disclosures: Assessing when a disclosure is worthwhile. Journal of Public Policy \& Marketing, Vol. 31 No.2, pp. 313-322.

Lang, M. and Lundholm, R. (1996), Corporate disclosure policy and analyst behavior. Accounting Review, Vol. 71 No. 4, pp. 467-492.

Latimer, P. and Maume P. (2015), Promoting Information in the Marketplace for Financial Services: Financial Market Regulation and International Standards. Springer International Publishing, Switzerland.

Lobo, G. and Zhou, J. (2001), Disclosure quality and earnings management. Asia Pacific Journal of Accounting and Economics, Vol. 8 No. 1, pp. 1-20.

Luo, W., Guo, X., Zhong, S., and Wang, J. (2019), Environmental information disclosure quality, media attention and debt financing costs: Evidence from Chinese heavy polluting listed companies. Journal of Cleaner Production, Vol. 231 pp. 268-277.

Mallin, C. Dunne, T. Helliar, C. and Ow-Yong, K. (2004), FRS 13 and corporate governance: a fund management perspective. Qualitative Research in Accounting and Management, Vol. 1, No. 2, pp. 17-42.

McInnes A. (2020), The regulation of financial planning in Australia: Current practice, issues and empirical analysis Routledge, Abingdon, UK.

McKeown, W. (2017), Financial Planning (2nd Ed.) Wiley, New York NY.

Murphy B. (2018), 'Financial Planning and Accounting in Australia: A Contest for Jurisdiction 1980- 2014' PhD Thesis. University of Wollongong, Wollongong. 
Nagar, V. Schoenfeld, J. and Wellman, L. (2019), The effect of economic policy uncertainty on investor information asymmetry and management disclosures. Journal of Accounting and Economics, Vol. 67, No. 1, pp. 36-57.

Naynar, N. R., Ram, A. J., and Maroun, W. (2018), Expectation gap between preparers and stakeholders in integrated reporting. Meditari accountancy research.Vol. 26 No.2, pp. 241-262

North, G. (2015), Regulation governing the provision of credit assistance and financial advice in Australia: A consumer's perspective. Federal Law Review, Vol. 43 No. 3, pp. 369396.

Organisation for Economic Co-operation and Development. (OECD) (2015), G20/OECD Principles of Corporate Governance. OECD Publishing, Paris

Parliamentary Joint Committee on Corporations and Financial Services. (PJCCFS) (2007), The structure and operation of the superannuation industry. Report for Parliament of Australia. Senate Printing Unit, Parliament House, Canberra.

Parliamentary Joint Committee on Corporations and Financial Services. (PJCCFS) (2009), Inquiry into financial products and services in Australia. Report for Parliament of Australia. Senate Printing Unit, Parliament House, Canberra.

Parliamentary Joint Committee on Corporations and Financial Services. (PJCCFS) (2012a), Corporations Amendment (Future of Financial Advice) Bill 2011 and Corporations Amendment (Further Future of Financial Advice Measures) Bill 2011. Report for Parliament of Australia. Senate Printing Unit, Parliament House, Canberra.

Parliamentary Joint Committee on Corporations and Financial Services. (PJCCFS) (2012b), Inquiry into the collapse of Trio Capital. Report for Parliament of Australia. Senate Printing Unit, Parliament House, Canberra.

Parliamentary Joint Committee on Corporations and Financial Services. (PJCCFS) (2014), Inquiry into proposals to lift the professional, ethical and education standards in the financial services industry. Report for Parliament of Australia. Senate Printing Unit, Parliament House, Canberra.

Parliament of Australia. (2017), 'Role of the Committee'. available at http://www.aph.gov.au/Parliamentary_Business/Committees/Joint/Corporations and Financial_Services/Role of the Committee. (accessed 4 July 2017)

Patten, D. M. and Trompeter, G. (2003), Corporate responses to political costs: an examination of the relation between environmental disclosure and earnings management. Journal of Accounting and Public Policy, Vol. 22 No. 1, pp. 83-94.

Richards, D. W. and Morton, E. (2020), Conceptualising Financial Advice in Australia: The Impact of Business Models and External Stakeholders on Client's Best Interest Practice. Financial Services Review, Vol. 28 No.2, pp. 133-158

Richardson, V. J. (2000), Information asymmetry and earnings management: Some evidence. Review of Quantitative Finance and Accounting, Vol. 15 No. 4, pp. 325-347. 
Sah, S. (2012), Conflicts of interest and your physician: psychological processes that cause unexpected changes in behavior. The Journal of Law, Medicine \& Ethics, Vol. 40 No. 3, pp. 482-487.

Sah, S. and Loewenstein, G. (2014), Nothing to declare: Mandatory and voluntary disclosure leads advisors to avoid conflicts of interest. Psychological science, Vol. 25 No. 2, pp. 575-584.

Sah, S. Malaviya, P., and Thompson, D. (2018), Conflict of interest disclosure as an expertise cue: Differential effects due to automatic versus deliberative processing. Organizational Behavior and Human Decision Processes, Vol. 147, pp. 127-146.

Saha, A. Morris, R. D., and Kang, H. (2019), Disclosure Overload? An Empirical Analysis of International Financial Reporting Standards Disclosure Requirements. Abacus, Vol. 55 No. 1, pp. 205-236.

Sahi, S. K. and Arora, A. P. (2012), Individual investor biases: a segmentation analysis. Qualitative Research in Financial Markets. Vol. 4 No. 1, pp. 6-25

Qu, S. Q. and Dumay, J. (2011), The qualitative research interview. Qualitative Research in Accounting \& Management. Vol. 8 No. 3, pp. 238-264

Schmidt, J. and Wilkins, M. S. (2013), Bringing darkness to light: The influence of auditor quality and audit committee expertise on the timeliness of financial statement restatement disclosures. Auditing: A Journal of Practice \& Theory, Vol. 32 No. 1, pp. 221-244.

Sharar, Z. (2006), 'A comparative analysis of the corporate governance legislative frameworks in Australia and Jordan measured against the OECD Principles of Corporate Governance 2004 as an international benchmark', $\mathrm{PhD}$ thesis. Bond University, Gold Coast.

Steen, A. McGrath, D. and Wong, A. (2016), Market failure, regulation and education of financial advisors. Australasian Accounting, Business and Finance Journal, Vol. 10 No. 1, pp. 3-17.

Stolowy, H., and Paugam, L. (2018). The expansion of non-financial reporting: an exploratory study. Accounting and Business Research, Vol. 48 No. 5, pp. 525-548.

Trueman, B. and Titman, S. (1988), An explanation for accounting income smoothing. Journal of Accounting Research, Vol. 26, pp. 127-139.

Welker, M. (1995), Disclosure policy, information asymmetry, and liquidity in equity markets. Contemporary Accounting Research, Vol. 11 No. 2, pp. 801-827.

Warschauer, T. (2002), The Role of Universities in the Development of the Personal Financial Planning Profession. Financial Services Review, Vol. 11 No. 3, pp. 201216. 
Table 1. Overview of the key reports

\begin{tabular}{|c|c|c|c|c|}
\hline $\begin{array}{l}\text { Report } \\
\text { Number }\end{array}$ & Citation & Submissions & Pages & Report Name \\
\hline 1 & Hayne (2019) & & 530 & $\begin{array}{l}\text { Final Report Royal Commission into Misconduct } \\
\text { in the Banking, Superannuation and Financial } \\
\text { Services Industry Volume } 1\end{array}$ \\
\hline 2 & Hayne (2018) & 10,323 & 375 & $\begin{array}{l}\text { Interim Report Royal Commission into } \\
\text { Misconduct in the Banking, Superannuation and } \\
\text { Financial Services Industry Volume } 1\end{array}$ \\
\hline 3 & PJCCFS (2014) & 39 & 103 & $\begin{array}{l}\text { Inquiry into proposals to lift the professional, } \\
\text { ethical and education standards in the financial } \\
\text { services industry - } 2014\end{array}$ \\
\hline 4 & PJCCFS (2012b) & 77 & 204 & Inquiry into the collapse of Trio Capital - 2012 \\
\hline 5 & PJCCFS (2012a) & 69 & 220 & $\begin{array}{l}\text { Corporations Amendment (Future of Financial } \\
\text { Advice) Bill } 2011 \text { and Corporations Amendment } \\
\text { (Further Future of Financial Advice Measures) Bill } \\
2011\end{array}$ \\
\hline 6 & PJCCFS (2009) & 407 & 209 & $\begin{array}{l}\text { Inquiry into financial products and services in } \\
\text { Australia }\end{array}$ \\
\hline 7 & PJCCFS (2007) & 96 & 198 & $\begin{array}{l}\text { The structure and operation of the superannuation } \\
\text { industry }\end{array}$ \\
\hline
\end{tabular}


Table 2: Overview of in-depth interviews

\begin{tabular}{|l|l|l|l|l|}
\hline Identifier & $\begin{array}{l}\text { Duration } \\
\text { (HH:MM:SS) }\end{array}$ & $\begin{array}{l}\text { Experience of } \\
\text { respondent in } \\
\text { financial } \\
\text { services }\end{array}$ & Position & Company Size \\
\hline A & $00: 53: 24$ & 12 years & Financial Planner & $\begin{array}{l}\text { Large Corporation } \\
1000+\text { employees }\end{array}$ \\
\hline B & $01: 12: 05$ & 29 years & $\begin{array}{l}\text { Business } \\
\text { Owner/Financial } \\
\text { Planner }\end{array}$ & $\begin{array}{l}\text { Boutique } \\
0-5 \text { employees }\end{array}$ \\
\hline C & $00: 51: 55$ & 17 years & $\begin{array}{l}\text { Financial } \\
\text { Planner/Partner }\end{array}$ & Medium Firm 150+ employees \\
\hline D & $01: 09: 01$ & 16 years & $\begin{array}{l}\text { Governance } \\
\text { Director }\end{array}$ & Medium Firm 150+ employees \\
\hline E & $01: 03: 39$ & 10 years & $\begin{array}{l}\text { Business Owner / } \\
\text { Financial Planner }\end{array}$ & $\begin{array}{l}\text { Boutique } \\
0-5 \text { employees }\end{array}$ \\
\hline F & $01: 03: 41$ & 5 years & Financial Planner & $\begin{array}{l}\text { Large } \\
\text { Corporation } \\
50,000+\text { employees }\end{array}$ \\
\hline G & $00: 38: 25$ & 17 years & $\begin{array}{l}\text { Business Owner/ } \\
\text { Financial Planner }\end{array}$ & $\begin{array}{l}\text { Small Firm } \\
5-50 \text { employees }\end{array}$ \\
\hline H & $00: 46: 36$ & 28 years & $\begin{array}{l}\text { Business Owner/ } \\
\text { Financial Planner }\end{array}$ & $\begin{array}{l}\text { Boutique } \\
0-5 \text { employees }\end{array}$ \\
\hline I & $00: 33: 43$ & 14 years & Financial Planner & $\begin{array}{l}\text { Boutique } \\
0-5 \text { employees }\end{array}$ \\
\hline J & $00: 22: 48$ & 20 years & Financial Planner & $\begin{array}{l}\text { Boutique } \\
0-5 \text { employees }\end{array}$ \\
\hline K & $00: 36: 44$ & 5 years & Financial Planner & $\begin{array}{l}\text { Large } \\
\text { Corporation } \\
50,000+\text { employees }\end{array}$ \\
\hline L & $00: 37: 10$ & 18 years & Senior Manager & \begin{tabular}{l} 
Medium Firm 150+ employees \\
\hline
\end{tabular} \\
\hline
\end{tabular}


Figure 1: Overview of Disclosure Documents in Financial Planning in Australia

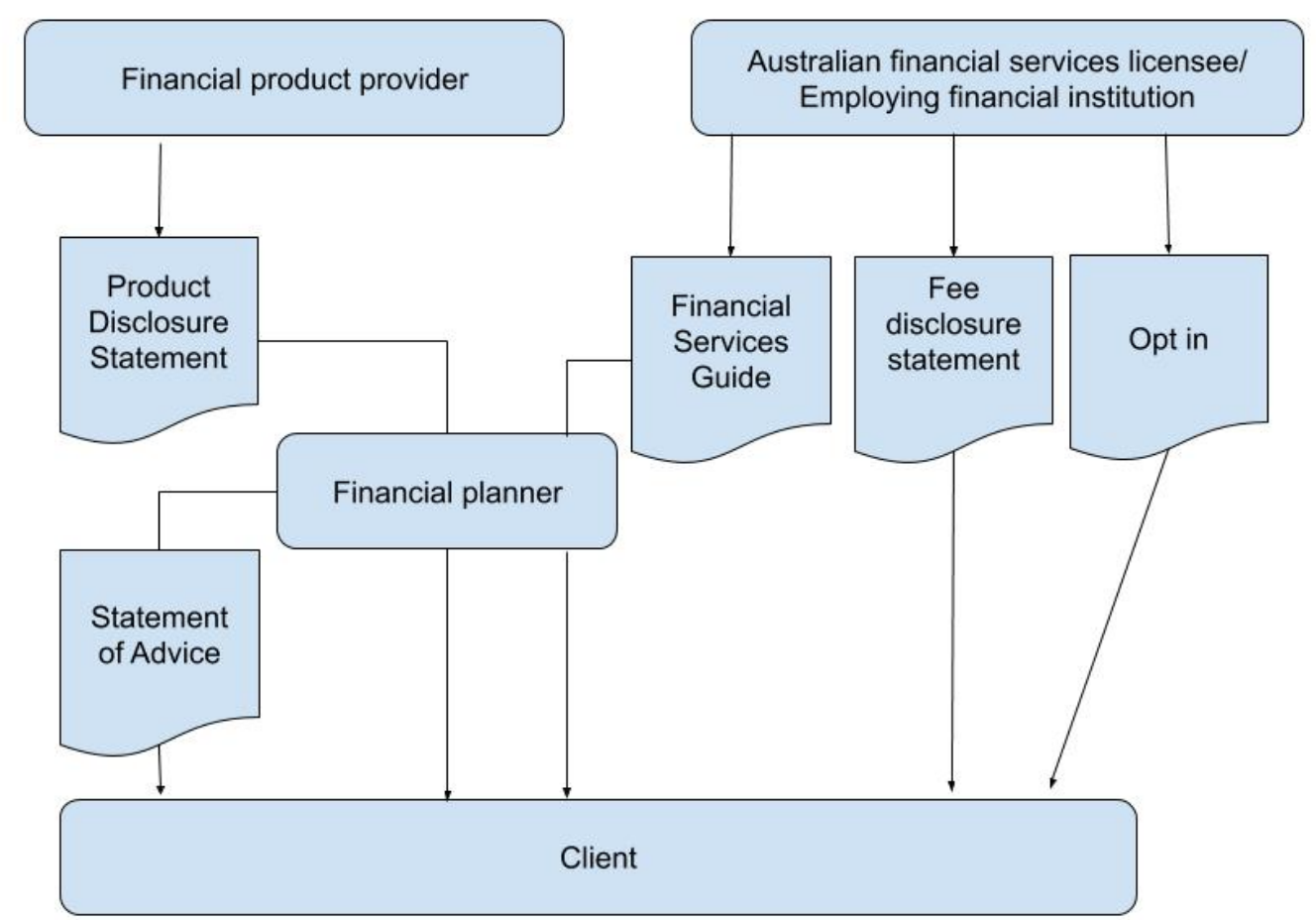

